УДК 342.924

DOI https://doi.org/10.32837/pyuv.v0i1(30).525

\author{
C. O. Матросова \\ orcid.org/0000-0001-9613-6831 \\ аспірантка юридичного факультету \\ Дніпровського національного університету ілені Олеся Гончара
}

\title{
ДЕРЖАВНА РЕССТРАЦІЯ В НІМЕЧЧИНІ: СТАНОВЛЕННЯ, РОЗВИТОК, СУЧАСНИЙ СТАН
}

Вступ. Потреба в реєстрації прав на нерухомість виникла в Німеччині у V - VI століттях у зв'язку з практикою позик під заставу ділянок. Спочатку з'явилися іпотечні книги. Пізніше такі записи набули систематичного характеру. У німецькому праві період з VII по XII століття був часом становлення судової форми передачі землі. Ця форма збереглася до теперішнього часу. Завдяки такому способу було можливим довести законність передачі прав; публічність, що надає третім особам можливість заявити свої претензії і захищає набувача від подальших претензій. Судова передача була вигідна набувачам землі і необхідна публічній владі як засіб контролю над переходом землі з рук у руки.

Виклад основного матеріалу. Основний період в історії формування поняття «нерухомості» характеризується тим, що під нерухомим майном розумілася земля, земельні ділянки. В основних правових актах окремих держав, зокрема Німеччини, зазначалося, що нерухомість - це земля, а багаторічні насадження, споруди й інше - це невід'ємні елементи (облаштування, поліпшення) земельної ділянки. Законодавці інших країн навіть не визнали за потрібне взагалі давати визначення терміну «нерухомість», вважаючи його само собою зрозумілим. В результаті цього на юридичній мові багатьох країн термін «нерухомість» ототожнюється з терміном «земля». Наприклад, земельне законодавство - законодавство про нерухомість, земельна реєстраційна система - система реєстрації прав на нерухоме майно.

В першій половині XII століття в деяких містах німецьких земель виник звичай записувати дані, які виникли на основі судових рішень передачі земель у міські книги. Спочатку ці записи носили значення публічного документа, що доводить вчинення акту передачі. Потім запис став істотною частиною процедури перенесення права власності, до якої приурочувався перехід речового права. Іноді запис поглинав судове рішення, перетворюючи його в просту формальність $[1$, с. 8].

Як зазначає Л.Ю. Василєвська у монографії «Учение о вещных сделках по германскому праву», модель реєстрації прав у Німеччині відбувалася так: перехід (виникнення, припинення, обтяження) прав на нерухоме майно здійснювалися в результаті наявної сукупності: речовий договір, який укладався сторонами, та запис у поземельній книзі [2, с. 262].

Німецькі вчені стверджують, що набувач нерухомого майна ставав власником тільки тоді, коли він був внесений до поземельної книги. Поземельна книга в Німеччині називалася "Grundbuch" (Грундбух) - це державний реєстр прав на земельні ділянки, який заводився на кожного власника або на кожну земельну ділянку [3, с. 423].

Відповідно до Правил земельної книги (Grundbuchordnung) регламент земельної книги в редакції оголошення від 26 травня 1994 року (Бюлетень федеральних законів I стор. 1114), в який в останній раз вносилася поправка відповідно до статті 11 Закону від 12 грудня 2019 року (Бюлетень федеральних законів I стор. 2602), повноваження по веденню поземельних книг були покладені на місцеві окружні суди. Місцеві окружні суди проводили реєстрацію об'єктів нерухомого майна за місцем їх знаходження у відповідних округах. Зберігалися земельні книги також у місцевих судах (органах земельного кадастру) [4, с. 20].

У німецькому праві використовувалося більш вузьке поняття нерухомості, до якої належали земля і суттєві складові частини земельної ділянки - речі, міцно пов'язані з землею (будови), продукти земельної ділянки, поки вони пов'язані з землею (насіння з моменту посіву, рослини 3 моменту їх посадки), а також права, пов'язані з правом власності на земельну ділянку. Рухомими речами Німецьке цивільне укладення визнало: 1) замінні речі - «речі, які в цивільному обороті визначалися числом, мірою або вагою» ; 2) споживані речі - «речі, використання яких відповідно до їх призначення полягало в їх споживанні або відчуженні" [1, с. 78].

Слід зазначити, що держава, визнаючи право власності як повну владу над річчю, резервувала для себе право накладати на неї ті чи інші обмеження. Важливі обмеження права власності були пов'язані зі зменшенням обсягу прав власників земельних ділянок. Так, відповідно до Німецького цивільного укладення «право власника земельної ділянки поширювалося як на простір, що знаходився над поверхнею, так і на надра землі». Однак «власник не міг заборонити вплив на такій висоті 
або глибині, якщо усунення впливу не становило для нього інтересу».

Крім того, було встановлено, що «власник земельної ділянки не міг заборонити проникнення до нього з іншої ділянки газів, парів, запаху, диму, кіптяви, шумів, струсу та інших подібних впливів, якщо вони не впливають або незначно впливають на використання ділянки», а також якщо «суттєве втручання було викликано звичайним у цій місцевості використанням земельної ділянки і не могло бути припинено економічно допустимими заходами, прийняття яких можна було вимагати від користувачів земельної ділянки» [1, с. 79].

Відповідно до параграфу 879,870 Німецького цивільного уложення при виникненні ситуації при черговості множинності прав, які обтяжували земельну ділянку, визначалися в тому випадку, якщо ці права були внесені до одного й того ж розділу поземельної книги за часовою послідовністю реєстрації цих прав. Тобто, пріоритет визнавався за тим правом, яке було датовано більш раннім числом; права, датовані одним і тим же числом, мали однакову юридичну силу [5, с. 201].

Автор статті розглядає механізм безпосередньої реєстрації у романських правових системах: заява подавалася будь-якою стороною угоди незалежно від іншої. Пояснюється це тим, що реєстр прав і договорів виконував принципово іншу функцію: крім реєстрації прав, мало місце і забезпечення публічності (гласності) договорів, які пов'язували з виникнення не лише речового права, а й фіксації переваг перед іншими покупцями.

Підсумовуючи викладене, можна стверджувати, що в Україні з прийняттям Закону України «Про державну реєстрацію речових прав на нерухоме майно та їх обтяжень» запропонований законодавцем удосконалений механізм державної реєстрації, який спрямований на забезпечення оптимізації та спрощення процедури державної реєстрації речових прав на нерухоме майно та їх обтяжень [6, с. 77].

Висновки. Фіксація права власності на нерухоме майно, так звана реєстрація прав, виникла в Німеччині у V - VI століттях. Формою реєстрації прав було занесення відомостей про майно та власника у Поземельну книгу. Поземельні книги велися за принципом територіальності - по округах. Набувач нерухомого майна ставав власником тільки тоді, коли він був внесений до поземельної книги. Поземельна книга в Німеччині називалася “Grundbuch". «Грундбух» $\mathrm{\epsilon}$ і нині державним реєстром прав на земельні ділянки, який заводиться на кожного власника або на кожну земельну ділянку. Реєстрацію правочинів (перехід прав) здійснювали нотаріуси. Така система реєстрації (зокрема, розвиток і становлення) дуже схожа на систему державної реєстрації в Україні. До схожості систем також можна віднести гласність, відкритість.
Щодо відмінностей у системі державної реєстрації прав у Німеччині, то можна зазначити, що реєстри будівель і споруд розглядалися як додаткові й існували поза системою земельного кадастру, що було дивним для багатоцільового земельного кадастру Німеччини, мета якого - створення багатоцільової земельно-інформаційної системи. Також до відмінностей із національною системою реєстрації прав можна віднести те, що поземельна книга велася судом першої інстанції, а в землі Баден-Вюртемберг - нотаріусом. У суді за ведення поземельної книги відповідало спеціальне відомство.

\section{Jimepamypa}

1. Системы регистрации прав на недвижимое имущество. Опыт зарубежных стран / Под ред. А.А. Лазаревского. М. : Фонд «Институт экономики города», 2000. C. 176.

2. Василевская Л.Ю. Учение о вещных сделках по германскому праву. М. : Статут, 2004. С. 538.

3. Жалинский А.Э., Рерихт А.А. Введение в немецкое право. М. : Спарк, 2001. С. 767.

4. Ястребова В.В. Регистрация вещных прав на недвижимое имущество в Российской Федерации и Федеративной Республике Германии : автореф. дис. канд. юрид. наук: 12.00.03. М., 2007. С. 180.

5. Германское право. Гражданское уложение / Пер. с нем. М. : Международный центр финансово-экономического развития, 1996. Ч. 1. С. 552.

6. Дякович M.M. Нотаріус як державний реєстратор прав на нерухоме майно за законодавством України [Електронний ресурс] / М.М. Дякович // Бюлетень Міністерства юстиції України: Офіційне видання. Київ, 2014/2. № 7. С. 73-77.

\section{Анотація}

Матросова С. О. Державна реєстрація в Німеччині: становлення, розвиток, сучасний стан. - Стаття.

У статті розглянуто теоретичні та практичні аспекти правової природи становлення, розвитку та сучасного стану державної реєстрації в Німеччині. Проаналізовано сутність та особливості механізму державної реєстрації прав у Німеччині. Актуальність цієї тематики зумовлена наявністю значної кількості прогалин з боку національного законодавства, яке регулює відносини безпосередньо у сфері державної реєстрації речових прав на нерухоме майно, їх обтяжень. Дослідивши досвід інших країн світу, можна зробити висновки та запропонувати інструменти для усунення прогалин і більш ефективного збереження, забезпечення і захисту прав осіб (фізичних чи юридичних), гарантованих законодавством.

У статті досліджено систему державної реєстрації Німеччини, країни, яка стала базою та прототипом для української системи реєстрації. Право власності це базовий правовий інститут у кожній країні світу. Виникнення, розвиток цього інституту - показник економічного зростання країни. Захист правового інституту прав власності є невід'ємним складником у розвинутій державі. З метою правильного розуміння та тлумачення сутності становлення інституту прав власності, зокрема закріплення (реєстрації) прав за конкретною особою, необхідно дослідити процес виникнення та формування витоків виникнення (закріплення) прав у минулому.

Аналіз публікацій свідчить про відсутність комплексних досліджень, розрізненість наукової літера- 
тури. Дослідженням цієї теми займалися українські науковці 0.О. Губанов, М.В. Жушман, Д.І. Змитрович, М.П. Ільницький, А.А. Литвиненко, Т.В. Лісніча, К.І. Людькова, Я.П. Павлович-Сенета, М.С. Рибак, М.B. Різак та інші.

Мета статті - проаналізувати витоки, розвиток та становлення системи державної реєстрації в Німеччині, оскільки саме ця країна стала прототипом національної системи державної реєстрації. Проаналізувавши та виявивши сильні позиції системи державної реєстрації, можливо запропонувати конкретні дії для реформування національної системи державної реєстрації в Україні.

Ключові слова: реєстр нерухомості, реєстр нерухомого майна, система реєстрації, реєстрація прав на нерухоме майно, права на нерухоме майно.

\section{Summary}

Matrosova Ye. O. State registration in Germany: formation, development, current state. - Article.

The article deals with the theoretical and practical aspects of the legal nature of the formation, development and current state of state registration in Germany. The essence and peculiarity of the mechanism of state registration of rights in Germany are analyzed. The relevance of this topic is due to the presence of a large number of gaps on the part of national legislation that regulates relations directly in the field of state registration of real rights to real estate, their encumbrances (hereinafter registration of rights). By examining the experience of other countries in the world, we will be able to draw conclusions and offer tools to address the loopholes and more effectively preserve, safeguard and protect the rights of individuals (natural or legal) as guaranteed by law.

This article will explore the state registration system of Germany, the country that became the basis and prototype for the Ukrainian registration system. Ownership is the basic legal institute in every country in the world. The emergence, development of this institute is an indicator of economic growth of the country. The protection of the property law institute is an integral part of a developed country. In order to properly understand and interpret the essence of becoming an institution of property rights, in particular the assignment (registration) of rights to a specific person, it is necessary to study the process of origin and formation of origins (establishment) of rights in the past.

The analysis of publications shows that there is no comprehensive research, the lack of scientific literature. The following Ukrainian scientists were engaged in the research of this topic 0.O. Gubanov, M.V. Zhushman, D.I. Zmitrovich, M.P. Ilnitsky, A.A. Litvinenko, T.V. Lisnich, K.I. Lyudkova, Ya.P. Pavlovich-Seneta, M.S. Rybak, M.V. Cutter and others.

Thus, the purpose of the article is to analyze the origins, development and formation of the state registration system in Germany, since this country became the prototype of the national state registration system. Having analyzed and identified the strong positions of the state registration system, it is possible to propose concrete actions for reforming the national state registration system.

Key words: real estate register, real estate register, registration system, registration of real estate rights, real estate rights. 